\title{
Acute Grief: Pengalaman Duka saat Ibu Kehilangan Perinatal
}

\author{
Erni Samutri1, Widyawari2, Wenny Artanty Nisman2 \\ 1Universitas Alma Ata Yogyakarta \\ 2Program Magister Keperawatan, Fakultas Kedokteran Keseharan Masyarakat dan Keperawatan, \\ Universitas Gadjah Mada \\ Correspondence author: Erni Samutri Telepon: 081288397167, E-mail: samutri7@gmail.com
}

DOI: https://doi.org/10.33859/dksm.v10il.445

\begin{abstract}
Abstrak
Latar Belakang: Kehilangan perinatal terjadi karena kematian janin pada usia lebih dari 22 minggu dan kematian bayi baru lahir hingga usia 28 hari kehidupan. Respon duka yang terjadi pada empat hingga enam minggu setelah peristiwa kematian janin/bayi disebut acute grief (duka akut) dan dianggap sebagai respon yang normal. Pada kehilangan perinatal, pengalaman acute grief yang tidak dikelola dengan tepat akan meningkatkan kerentanan ibu untuk mengalami gangguan kelekatan pada kehamilan berikutnya maupun gangguan psikologis.

Tujuan: Penelitian ini bertujuan untuk mengeksplorasi pengalaman acute grief pada ibu dengan kehilangan perinatal dan upaya yang dilakukan ibu untuk mengelola duka yang dialami.

Metode: Partisipan dalam penelitian ini adalah ibu dengan pengalaman kehilangan perinatal yang dipilih dengan teknik purposive sampling. Jumlah partisipan hingga tercapai saturasi data dalam penelitian ini adalah 9 partisipan. Kriteria inklusi penelitian ini yaitu a) ibu dengan pengalaman acute grief karena kehilangan perinatal, b) lama kehilangan perinatal yaitu 7 minggu -2 tahun. Analisa data pada penelitian ini menggunakan modified Stevick-Colaizzi-Keen.

Hasil: Penelitian ini menghasilkan tiga temuan tema yaitu ibu mengalami berbagai perasaan duka yang bercampur menjadi satu, ada kekosongan setelah kehilangan perinatal, dan pendekatan spiritual sebagai strategi koping yang bermakna.

Kesimpulan: Kehilangan perinatal telah mengarahkan ibu pada pengalaman acute grief. Strategi koping pendekatan spiritual menjadi strategi yang digunakan oleh semua ibu dan memberikan hasil yang bermakna bagi kestabilan emosional ibu. Perlu adanya peran aktif dari tenaga kesehatan dalam memberikan dukungan psikologis dan atau konseling kepada ibu untuk membangun strategi koping yang adaptif dan meningkatkan outcome kesehatannya.
\end{abstract}

Kata Kunci: kehilangan perinatal, acute grief, koping, pendekatan spiritual. 


\begin{abstract}
Background: Perinatal loss occurs due to the death of a fetus at the age over 22 weeks and the death of newborn babies up to 28 days of life. Acute grief defined as response of grief that occurs at four to six weeks immediately after the events of fetus/ baby death and is considered as a normal response. Acute grief experience which is not managed properly will increase the vulnerability of women to experience attachment disorder on subsequent pregnancies as well as psychological disorder.

Objective: This study aims to explore the experience of acute grief on mothers with perinatal loss and their efforts to manage the grief responses.

Methods: Mothers with perinatal loss as a participant were selected using purposive sampling technique. Data saturation in this research was reached in the ninth participant. Inclusion criteria for the study is a) mother with acute grief experience due of perinatal loss, $b$ ) the length of perinatal loss was 7 weeks-2 years. Data were analyzed using the modified Stevick-Colaizzi-Keen method.

Results: Three themes which emerge in this study are mother experiences various feelings of grief that mixed into one, emptiness after perinatal loss, and spiritual approach is a meaningful coping strategy.

Conclusion: Perinatal loss has brought the mother to experience acute grief. Spiritual approaches used by all mothers and provide meaningful results for their emotional stability. An active role of health care provider in providing psychological support and counseling is strongly needed to build adaptive koping strategies and improve mother health outcome after perinatal loss.
\end{abstract}

Keyword: perinatal loss, acute grief, coping, spiritual approach. 
Dinamika Kesehatan Jurnal Kebidanan dan Keperawatan Vol 10 No. 1 Juli 2019 (ISSN: 2086-3454 EISSN: 2549-4058) url: http://ojs.dinamikakesehatan.unism.ac.id DOI : https://doi.org/10.33859/dksm.v10il

Acute Grief: Pengalaman Duka saat Ibu Kehilangan Perinatal

\section{Pendahuluan}

Kematian perinatal didefinisikan sebagai kombinasi kematian janin (stillbirth) pada usia minimal 20 minggu hingga kematian neonates maksimal pada usia 28 hari di awal kehidupan (Zacharias, 2017). Data WHO menunjukkan bahwa pada tahun 2009 angka bayi lahir mati (stillbirth) telah mencapai 2,6 juta dan diikuti angka kematian neonatal yaitu sebanyak 2,8 juta. Pada negara berkembang seperti Amerika Serikat, angka kematian perinatal juga tidak menunjukkan perubahan signifikan dari tahun 2014 hingga 2016 yaitu 6 kematian perinatal setiap 1.000 kelahiran (CDC, 2018). Sementara itu, di Negara berkembang seperti Indonesia, angka kematian perinatal masih cukup tinggi yaitu 26 kematian perinatal per 1.000 kelahiran hidup berdasarkan SurveI Demografi Kesehatan Indonesia (SDKI) tahun 2012.

Angka kematian perinatal yang tinggi, selain menyebabkan penurunan populasi anak yang akan menjadi generasi penerus, juga berdampak pada orang terdekat yang ditinggalkan terutama ibu. Dampak yang timbul seperti gangguan fisik, emosional, psikologis, maupun spiritual (Puia et al., 2013), akan saling berinteraksi dan memunculkan respon berduka (Gould, 2010). Duka terhadap peristiwa kehilangan yang bermakna akan membawa individu pada lima jenis respon yang seragam pada berbagai jenis kehilangan, meliputi 1) distress somatic; 2) fokus/ asyik terhadap gambaran orang yang telah meninggal; 3) rasa bersalah; 4) reaksi memusuhi; dan 5) hilangnya pola aktivitas dan interaksi. Berbagai respon duka ini dikatakan normal jika dialami selama empat hingga enam minggu setelah peristiwa kematian janin/ bayi, yang dikenal dengan acute grief (duka akut) (Lindemann, 1944). Penelitian Lindemann (1944) pada partisipan dengan berbagai jenis kehilangan seperti kematian anggota keluarga karena sakit; korban bencana; dan anggota keluarga tentara yang ditinggal ke medan perang, menunjukkan bahwa penggunaan manajemen duka yang tepat akan menghindarkan individu dari respon duka yang memanjang (prolonged grief), complicated grief, atau duka patologis yang lain. 
Dinamika Kesehatan Jurnal Kebidanan dan Keperawatan Vol 10 No. 1 Juli 2019 (ISSN: 2086-3454 EISSN: 2549-4058) url: http://ojs.dinamikakesehatan.unism.ac.id DOI : https://doi.org/10.33859/dksm.v10il

Acute Grief: Pengalaman Duka saat Ibu Kehilangan Perinatal

Identifikasi pengalaman duka pada

berbagai bentuk kehilangan perlu dilakukan

untuk mengetahui kecenderungan respon duka

yang dialami. Pada kehilangan perinatal, adanya complicated grief akan meningkatkan

kerentanan ibu untuk mengalami gangguan kelekatan pada kehamilan berikutnya (O’Leary, 2004), replacement child syndrome, post-traumatic stress disorder (ÜnstündagBudak, 2015), dan gangguan psikologis lainnya. Oleh karena itu, perlu dilakukan eksplorasi mendalam mengenai pengalaman duka pada ibu dengan kehilangan perinatal dan upayanya untuk meringankan pengalaman duka tersebut. Pemahaman tentang pengalaman duka ibu dan upayanya untuk bangkit dari duka, akan membantu tenaga kesehatan dalam meminimalkan terjadinya pengalaman duka patologis dan mencapai outcome kehamilan berikutnya yang lebih baik. Penelitian ini bertujuan untuk mengeksplorasi pengalaman duka akut (acute grief) pada ibu dengan kehilangan perinatal dan menggali upaya yang telah dilakukan ibu untuk mengelola duka yang dialaminya.

\section{Bahan dan Metode}

Partisipan dalam penelitian ini adalah ibu dengan pengalaman kehilangan perinatal di Wilayah kerja Puskesmas Mantrijeron dan Puskesmas Pleret, DIY. Partisipan dipilih menggunakan teknik purposive sampling sesuai dengan kriteria inklusi penelitian. Kriteria inklusi penelitian ini yaitu a) ibu dengan pengalaman duka akut (acute grief) karena kehilangan perinatal, b) lama kehilangan perinatal meliputi 7 minggu -2 tahun. Durasi waktu ini dipilih dengan asumsi bahwa respon acute grief akan berakhir 4-6 minggu (Lindemann, 1944) setelah peristiwa kehilangan perinatal dan pada minggu ke $7 \mathrm{ibu}$ telah siap untuk dilakukan eksplorasi mendalam. Kriteria eksklusi dalam penelitian ini adalah a) ibu yang menolak untuk menjadi partisipan, b) ibu yang mengalami duka patologis yang ditunjukkan dari rekam medis ibu di puskesmas dan tidak memungkinkan untuk dilakukan wawancara. Jumlah partisipan hingga tercapai saturasi data dalam penelitian ini adalah 9 partisipan yang ditandai dengan 
Dinamika Kesehatan Jurnal Kebidanan dan Keperawatan Vol 10 No. 1 Juli 2019 (ISSN: 2086-3454 EISSN: 2549-4058) url: http://ojs.dinamikakesehatan.unism.ac.id DOI : https://doi.org/10.33859/dksm.v10il

Acute Grief: Pengalaman Duka saat Ibu Kehilangan Perinatal

tidak diperolehnya kode baru pada wawancara partisipan ke 9.

Proses pengumpulan data dilakukan oleh peneliti pada bulan Januari hingga Februari 2018 dengan metode wawancara semiterstruktur menggunakan pedoman wawancara dan catatan lapangan. Pedoman wawancara pada topik penelitian ini meliputi 3 pertanyaan inti, yaitu "Bagaimana peristiwa kehilangan janin/ bayi yang pernah ibu alami?"; "Bagaimana perasaan ibu saat mengetahui janin/ bayi ibu telah meninggal?"; dan "Tindakan apa saja yang ibu lakukan untuk meringankan perasaan yang ibu rasakan?”. Selama proses wawancara, pertanyaanpertanyaan probing diberikan sesuai alur jawaban partisipan. Setiap partisipan dilakukan dua kali wawancara, dimana wawancara pertama dilakukan untuk mengeksplorasi pengalaman acute grief dan wawancara kedua untuk member checking dan triangulasi sumber. Wawancara kedua dilakukan setelah analisa hasil wawancara pertama selesai yaitu pada rentang 3-8 hari.
Analisa data pada penelitian ini dilakukan dengan metode yang dikemukakan oleh Moustakes (1994) yaitu modified StevickColaizzi-Keen. Metode ini meliputi 6 langkah analisa data yang sirkuler dengan proses pengumpulan data, yang meliputi 1) bracketing dengan menulis jurnal reflektif; mengidentifikasi pernyataan penting dari transkrip hasil wawancara; mengelompokkan pernyataan penting ke dalam kode, kategori, dan tema sementara; 4) melakukan member checking; 5) mengulang proses pengumpulan data dan analisa data pada langkah 1-4 hingga tercapai saturasi; 6) menulis deskripsi hasil akhir penelitian kedalam laporan.

Penelitian ini telah mendapatkan izin kelayakan etik dari komite etik Fakultas Kedokteran UGM dengan nomor KE/FK/1244/EC/2017 dan memperhatikan prinsip etik utama dalam penelitian kualitatif (Richards \& Schwartz, 2002) yaitu anonymity, confidenciality, dan informed consent. 
Dinamika Kesehatan Jurnal Kebidanan dan Keperawatan Vol 10 No. 1 Juli 2019 (ISSN: 2086-3454 EISSN: 2549-4058) url: http://ojs.dinamikakesehatan.unism.ac.id DOI : https://doi.org/10.33859/dksm.v10il

Acute Grief: Pengalaman Duka saat Ibu Kehilangan Perinatal

Hasil

\section{Karakteristik partisipan}

Identifikasi partisipan penelitian ini menggunakan angka dan kode. Identifikasi partisipan utama dengan kode $\mathrm{P} 1, \mathrm{P} 2, \mathrm{P} 3$ dan seterusnya dan identifikasi partisipan triangulasi dengan S5 untuk kode suami P5, I9 untuk kode ibu P9. Karakteristik lengkap partisipan ditunjukkan pada table 1.

Tabel 1. Karakteristik Partisipan Penelitian

\begin{tabular}{|c|c|c|c|c|c|c|c|}
\hline Kode & $\begin{array}{l}\text { Usia } \\
\text { (tahun) }\end{array}$ & Pendidikan & Agama & $\begin{array}{l}\text { Usia janin } \\
\text { 'bayi saat } \\
\text { meninggal }\end{array}$ & Jumlah anak & $\begin{array}{l}\text { Lama } \\
\text { kehilangan } \\
\text { perinatal }\end{array}$ & $\begin{array}{l}\text { Penyebab } \\
\text { perinatal }\end{array}$ \\
\hline P1 & 31 & SMA & Islam & 6 jam & 1 anak \& sedang hamil & 8 bulan & Asfiksia \\
\hline $\mathrm{P} 2$ & 40 & SD & Islam & 3 hari & 1 anak & 7 bulan & Berat Badan Lahir Rendah \\
\hline P3 & 23 & SMA & Islam & 3 hari & Belum ada anak & 8 bulan & Death on Arrival \\
\hline P4 & 27 & SMK & Islam & IUFD & 1 anak & 22 bulan & IUFD \\
\hline P5 & 43 & SMEA & Islam & 3 hari & 2 anak & 2 bulan & Penyakit Jantung Bawaan \\
\hline P6 & 39 & SD & Islam & 6 jam & 2 anak & 19 bulan & Aspirasi mekoneum \\
\hline P7 & 32 & SMP & Islam & 3 hari & Belum ada anak & 4 bulan & Prematur \\
\hline P8 & 27 & S1 & Hindu & 12 hari & 1 anak & 24 bulan & Penyakit jantung Bawaan \\
\hline P9 & 30 & SMA & Islam & IUFD & 1 anak & 26 bulan & Ibu dengan eklamsia \\
\hline
\end{tabular}

\section{Hasil analisis tema}

Penelitian ini menghasilkan tiga temuan tema yang menggambarkan pengalaman acute grief pada ibu dengan kehilangan perinatal, meliputi ibu mengalami berbagai perasaan duka yang bercampur menjadi satu; ada kekosongan setelah kehilangan perinatal; pendekatan spiritual sebagai strategi koping yang bermakna.

\section{Ibu mengalami berbagai perasaan duka} yang bercampur menjadi satu

Peristiwa kehilangan perinatal telah membawa ibu pada kumpulan respon berduka yang dapat muncul dalam satu waktu. Ibu mengungkapkan adanya respon fisik seperti menangis; kesulitan tidur, berbagai respon psikologis seperti sedih; marah; rasa bersalah; menyesal; campur aduk, dan berbagai respon sosial seperti menghindar dan takut terhadap respon lingkungan sekitar.

Pengalaman respon fisik seperti menangis diungkapkan oleh sebagian besar ibu, baik saat ibu mengetahui kematian bayinya maupun saat dilakukan 
Dinamika Kesehatan Jurnal Kebidanan dan Keperawatan Vol 10 No. 1 Juli 2019 (ISSN: 2086-3454 EISSN: 2549-4058) url: http://ojs.dinamikakesehatan.unism.ac.id DOI : https://doi.org/10.33859/dksm.v10il

Acute Grief: Pengalaman Duka saat Ibu Kehilangan Perinatal

proses wawancara. Seorang ibu

mengungkapkan:

“...Aku di rumah sakit aja ngosekngosek (nangis gulung-gulung) kok mbak, gak terima." (P3, 8 bulan setelah kehilangan perinatal).

Respon emosional yang muncul pada partisipan beragam dan bercampur menjadi satu sehingga membuat sebagian ibu mengungkapkan perasaan campur aduk. Beberapa ibu mengungkapkan:

“...campur aduk, ya nangis lah mbak.

Kehilangan anak gitu, apa ya, rasa sakitnya aja belum hilang. Terus yang lainnya juga, yang melahirkan disitu bayinya ada. Terus saya disitu sendiri." (P1, 8 bulan kehilangan perinatal).

“... Sedihhh gitu lho mbak. Kok kaya nggak, gimana ya, jengkelnya tu jengkel tapi kok, baru mau dikasih kok, diambil lagi. Mau marah, tapi sama siapa gitu." (P7, 4 bulan setelah kehilangan perinatal).
Rasa bersalah sebagai respon psikologis juga diungkapkan oleh sebagian besar ibu. Ibu mengingat- ingat kembali kesalahan apa yang telah dilakukan sehingga menyebabkan kematian janin/ bayi. Rasa bersalah ini juga diperberat dengan ungkapan dari lingkungan sosial ibu yang menyalahkan sikap ibu selama masa kehamilan. Seorang ibu mengungkapkan: “...Yaudah, udah jatuh ditimpa tangga pula, ngenes saya. Nangis saya, udah berasa semua kaya salah saya. Dibilang sama sodara, "siapa suruh kamu nggak minum obat”, na kalau bayi menolak mbak. Terus pas dedek meninggal itu, ada yang bilang gini "itu kamu gara-gara minum obat nggak mau. Rasain”." (P8, 24 bulan setelah kehilangan perinatal)

Respon sosial ditunjukkan ibu saat berinteraksi dengan orang sekitar. Ibu menujukkan sikap menarik diri dari lingkunganya dengan tidak bersedia mengikuti acara rutinitas masyarakat yang biasanya diikuti. Ibu mengungkapkan 
Dinamika Kesehatan Jurnal Kebidanan dan Keperawatan Vol 10 No. 1 Juli 2019 (ISSN: 2086-3454 EISSN: 2549-4058) url: http://ojs.dinamikakesehatan.unism.ac.id DOI : https://doi.org/10.33859/dksm.v10il

Acute Grief: Pengalaman Duka saat Ibu Kehilangan Perinatal

perasaan takut terhadap hal yang mungkin akan diungkapkan lingkungannya. Seorang ibu yang hingga saat ini belum hamil dan belum memiliki anak lagi mengungkapkan: “...Pernah mikir, ”orang diluar ngomongin aku apa ya?". Rasanya ya sedih. Tapi kalau saya itu, perasaan saya aja. Pas ngerasa gitu, rasanya kaya mau marah, tapi kan nggak ada kenyataannya gitu lho. Hanya perasaan saja gitu lho. Cuma ketakutan sendiri.." (P7, 4 bulan setelah kehilangan perinatal).

\section{Perasaan hampa setelah kehilangan} perinatal

Perasaan hampa dirasakan ibu karena ketidakadaan bayi yang seharusnya menemani ibu setelah menjalani persalinan. Ibu yang sebelumnya yakin akan memiliki bayi yang telah bertahuntahun diharapkan, kemudian berubah menjadi kesedihan dan kehampaan. Seorang ibu yang telah menunggu kehadiran bayinya selama 6 tahun mengungkapkan:
“...Kosongnya itu ya itu mbak, udah diaper-arepin lama to mbak. Terasa nihil gitu. Pas udah hamil, seneng banget kan mbak, wah, tinggal nunggu. Iya, udah bayangin beneran mbak itu, aku udah bayangin, udah ada. Yakin besok punya anak beneran. Kan gitu mbak. Tapi pas nyampe anunya, nggak mau dimomong. " (P7, 4 bulan setelah kehilangan perinatal) Perasaan kekosongan juga diungkapkan oleh seorang ibu yang sebelumnya sudah berinteraksi dan merawat bayinya selama 3 hari. Ibu mengungkapkan:

“...Di sini mbak (menunjuk dada) udah kosong-song gak ada. Ya pikirannya kosong tu kadang gini lho mbak, mikirnya sampai kebangetan, dulu aku sampai dimintain doa, ya intinya biar nggak kebablasan” (P3, 8 bulan kehilangan perinatal).

\section{Pendekatan spiritual sebagai strategi}

\section{koping yang bermakna}

Ibu mengupayakan berbagai strategi untuk mengelola perasaan 
Dinamika Kesehatan Jurnal Kebidanan dan Keperawatan Vol 10 No. 1 Juli 2019 (ISSN: 2086-3454 EISSN: 2549-4058) url: http://ojs.dinamikakesehatan.unism.ac.id DOI : https://doi.org/10.33859/dksm.v10i1

Acute Grief: Pengalaman Duka saat Ibu Kehilangan Perinatal

dukanya. Strategi yang diupayakan oleh

ibu meliputi menyibukkan diri dengan

aktivitas, fokus pada perawatan anak yang

lain, berbagi cerita dengan orang lain.

Namun, satu strategi koping yang

diungkapkan oleh semua ibu yaitu

pendekatan spiritual, telah mengarahkan

ibu untuk mengembangkan pikiran positif

dan menjadi lebih tenang. Ibu

mengungkapkan:

“... Iya, sholat sama berdoa itu yang terpenting. Ya saya masih syukur, soalnya tetangga desa itu juga ada, itu anaknya usia kandungan 8 bulan itu meninggalnya di dalam perut, terus keluarnya harus pakai operasi. Kalau saya kan normal, jadinya kan sembuhnya itu cepet. Kalau lihat, pokoknya saya menghiburnya ya liat yang udah-udah itu ada temen saya yang seperti saya, kehilangan anak, dia juga tegar, kenapa saya nggak bisa, kn cuma gitu aja.” (P1, 8 bulan setelah kehilangan perinatal).
Ibu yakin akan dipertemukan dengan janin/ bayinya yang telah meninggal pada masa yang akan datang. Seorang ibu mengatakan:

“...itu (kematian bayi P7) kan pelajaran hidup yang paling berharga kan, pokoknya ikhlas, sabar, mungkin ini cobaan to. Katanya kalau Gusti Alloh ngasih cobaan itu, sayang sama umatnya, kaya gitu. Terus bisa mbawa orang tuanya nanti, kan kaya gitu." (P7, 4 bulan setelah kehilangan perinatal)

Selain strategi yang dibangun oleh ibu sendiri, ibu juga memperoleh dukungan dari berbagai sumber. Dukungan dari ibu partisipan untuk mengekspresikan kesedihannya dengan menangis dan memotivasinya untuk bangkit, membuat ibu merasa lebih tenang. Namun disisi lain, ungkapan suami yang juga bertujuan untuk menenangkan, kadang justru menjadi beban pikiran ibu. Salah satu partisipan triangulasi yaitu suami memperkuat pernyataan ibu. Suami mengatakan: 
Dinamika Kesehatan Jurnal Kebidanan dan Keperawatan Vol 10 No. 1 Juli 2019 (ISSN: 2086-3454 EISSN: 2549-4058) url: http://ojs.dinamikakesehatan.unism.ac.id DOI : https://doi.org/10.33859/dksm.v10i1

Acute Grief: Pengalaman Duka saat Ibu Kehilangan Perinatal

“...Nek saya juga gitu, ”kamu tu

ngapain, kok diinget-inget terus, sudahlah doa saja, malah nggak papa, gak usah diinget-inget terus", gitu aja.Udah saya nasehatin banyak. Tapi ya ibunya sendiri masih kaya gitu aja, masih inget." (S5, 50 tahun).

\section{Pembahasan}

Pengalaman kehilangan perinatal telah membawa orang tua terutama ibu pada pengalaman duka yang mendalam. Pada penelitian ini ibu merasakan berbagai respon berduka yaitu menangis, kesulitan tidur, sedih, marah, bersalah, menyesal, campur aduk, serta menghindar dan takut terhadap respon lingkungan sekitar. Temuan ini sejalan dengan konsep acute grief (duka akut) yang dikemukakan oleh Lindemann (1944) bahwa acute grief merupakan sindrom dengan gejala somatik dan psikologis. Gejala somatik seperti menangis, tidak berdaya, nafas pendek, merasa tercekik, dan nyeri abdomen akan mengganggu aktivitas yang umumnya merupakan rutinitas ibu yang bisanya dijalani.
Untuk melakukan rutinitasnya, ibu harus berusaha keras dan merasakan bahwa rutinitas tersebut sebagai tugas baru yang asing bagi ibu (Lindemann, 1994). Gejala psikologis yang ditunjukkan dengan rasa sedih; mudah marah; rasa bersalah; dan bayangan akan kehadiran bayi yang telah meninggal (Lindeman, 1944; Gupta, et al., 2017; Burden et al., 2016), telah membuat ibu merasa jauh dari orang lain, bahkan dari anggota keluarganya. Hal ini membuat ibu menghidari lingkungannya untuk beberapa waktu hingga ibu siap untuk membina hubungan kembali (Frøen et al., 2011).

Sikap takut terhadap respon lingkungan sekitar juga diungkapkan oleh Kavanaugh (2004) dalam penelitiannya yang menemukan bahwa ibu merasa orang- orang disekitarnya telah mengabaikannya dan takut berinteraksi dengan ibu. Hal ini karena orang disekitar ibu tidak mengetahui apa yang harus dilakukan untuk membantu ibu yang mengalami kehilangan perinatal. Pengalaman inilah yang membuat ibu merasa sendiri dan merasa diabaikan (Kavanaugh, 2004). 
Dinamika Kesehatan Jurnal Kebidanan dan Keperawatan Vol 10 No. 1 Juli 2019 (ISSN: 2086-3454 EISSN: 2549-4058) url: http://ojs.dinamikakesehatan.unism.ac.id DOI : https://doi.org/10.33859/dksm.v10il

Acute Grief: Pengalaman Duka saat Ibu Kehilangan Perinatal

Perasaan hampa juga menjadi pengalaman yang dirasakan ibu setelah kehilangan janin/ bayinya. Kehadiran bayi yang telah lama diharapkan dalam keluarga dan harapan menjadi seorang ibu telah hilang ketika bayi dinyatakan meninggal. Hasil ini sejalan dengan temuan dalam penelitian Sutan \& Miskam (2012) dimana ibu telah merasakan kehilangan harapannya, kehilangan kedekatan, dan kehilangan hidup. Perasaan kosong dan duka yang memanjang dapat terjadi sebagai akibat kurangnya dukungan sosial yang diperoleh ibu, sehingga membuat ibu merasa sendiri (Badenhorst, 2007). Upaya pelayanan maternal segera setelah peristiwa kehilangan dengan menyediakan lingkungan perawatan yang sensitif dan penuh empati merupakan strategi yang tepat untuk membantu orang tua dengan kehilangan perinatal. Dukungan psikologis maupun konseling diyakini dapat meningkatkan outcome orang tua dan keluarga yang mengalami duka (Koopmans et al., 2013).

Strategi pengelolaan acute grief yang tepat akan membantu ibu mencapai kestabilan emosionalnya. Partisipan dalam penelitian ini menunjukkan bahwa pendekatan spiritual menjadi strategi koping yang mampu menenangkan ibu. Partisipan penelitian ini terdiri dari 8 ibu dengan agama Islam dan $1 \mathrm{ibu}$ dengan agama Hindu. Namun, pada kesembilan ibu merasakan bahwa upaya mendekatkan diri kepada Sang Pencipta telah membuatnya merasakan ketenangan dan keyakinan bahwa janin/ bayinya telah menunggu ibu dan akan dipertemukan di masa yang akan datang. Temuan yang serupa juga diungkapkan dalam penelitian Sutan \& Miskam (2012) bahwa ibu dengan kehilangan bayinya berusaha mempelajari hal-hal yang terkandung dalam kitab suci (Al Quran) untuk mencari makna kehilangan yang dialami. Ibu memahami bahwa hendaknya individu dapat menerima takdir Tuhan dan berfikir positif saat menghadapi situasi yang menekan (Sutan \& Miskam , 2012). Pada penelitian Arnold \& Gemma (2008) pada sebagian partisipan yang beragama Protestan juga mendeskripsikan bahwa bayinya telah bahagia di surga dan menunggu orang tuanya untuk bisa bersatu 
Dinamika Kesehatan Jurnal Kebidanan dan Keperawatan Vol 10 No. 1 Juli 2019 (ISSN: 2086-3454 EISSN: 2549-4058) url: http://ojs.dinamikakesehatan.unism.ac.id DOI : https://doi.org/10.33859/dksm.v10il

Acute Grief: Pengalaman Duka saat Ibu Kehilangan Perinatal

kembali. Temuan tersebut juga diungkapkan

dalam review yang dilakukan oleh

Allahdadian \& Irajpour (2015).

Selain itu, kesempatan untuk berbagi pengalaman dengan orang lain yang juga mengalami kehilangan, telah membantu ibu memahami pola duka yang dialami dan membantunya berfikir positif tentang kehidupannya. Review yang lakukan oleh Koopmans et al (2013) menunjukkan bahwa dukungan dari lingkungan sosial ibu secara signifikan dapat meningkatkan outcome ibu dengan kehilangan perinatal. Dukungan sosial terutama dari anggota keluarga dapat menurunkan tingkat kecemasan dan depresi pada ibu. Pemberian dukungan sosial dan psikologis yang tepat telah menjadi bagian dari strategi pengelolaan duka self- compassion (Neff, 2009).

Self-compassion memiliki tiga komponen yaitu self-kindness, common humanity, dan mindfulness. Strategi selfcompassion yang ditunjukkan partisipan dalam penelitian ini yaitu common humanity dengan berbagi cerita tentang dukanya dengan orang lain dan memperoleh dukungan psikologis dari keluarga terdekat. Kemudian mindfulness ditunjukkan dengan mendekatkan diri kepada Sang Pencipta sehingga mampu memaknai pengalaman kehilangannya secara positif. Namun, mayoritas ibu belum mampu menunjukkan self-kindness karena ibu masih memiliki rasa bersalah atas kematian bayinya. Oleh karena itu, perlu adanya peran aktif dari tenaga kesehatan dalam memberikan dukungan psikologis dan atau konseling kepada ibu untuk membangun strategi koping yang adaptif dan membantu mengembalikan kestabilan emosionalnya kembali (Koopmans et al., 2013).

\section{Kelemahan}

Semua partisipan dalam penelitian ini memiliki latar belakang budaya Jawa, sehingga eksplorasi pengalaman acute grief pada berbagai budaya di Indonesia belum dapat diidentifikasi. Padahal, budaya yang dianut individu akan mempengaruhi responnya terhadap kehilangan perinatal. Selain itu, penelitian ini hanya menggali pengalaman acute grief pada ibu dari janin/ 
Dinamika Kesehatan Jurnal Kebidanan dan Keperawatan Vol 10 No. 1 Juli 2019 (ISSN: 2086-3454 EISSN: 2549-4058) url: http://ojs.dinamikakesehatan.unism.ac.id DOI : https://doi.org/10.33859/dksm.v10il

Acute Grief: Pengalaman Duka saat Ibu Kehilangan Perinatal

bayi yang meninggal dan ayah hanya digunakan sebagai partisipan triangulasi. Sedangkan pada beberapa penelitian terdahulu (Koopmans et al., 2013; Burden et al., 2016) menunjukkan bahwa seorang ayah dari janin/ bayi yang meninggal juga menampilkan respon duka, namun dengan cara yang berbeda. Oleh karena itu, identifikasi lebih lanjut tentang respon duka pada kedua orang tua yang mengalami kehilangan perinatal pada berbagai latar belakang budaya perlu dilakukan. Upaya ini mungkin dapat membantu menentukan intervensi terbaik untuk orang tua dengan kehilangan perinatal dan meningkatkan outcome dari keluarga yang mengalami kehilangan ini.

\section{Kesimpulan}

Kehilangan perinatal telah mengarahkan ibu pada kumpulan respon duka. Acute grief muncul segera setelah peristiwa kehilangan perinatal yang dialami ibu dan membuat ibu merasakan respon duka yang bercampur menjadi satu. Selain respon fisik, psikologis, dan sosial, ibu juga merasakan kehampaan dalam perasaannya karena ketidakhadiran janin/ bayi yang telah dikandungnya. Berbagai strategi koping telah diupayakan ibu untuk meringan duka yang dialaminya. Strategi koping pendekatan spiritual menjadi strategi yang digunakan oleh semua ibu dan memberikan hasil yang bermakna bagi kestabilan emosional ibu. Sehingga, penting bagi tenaga kesehatan terutama di lingkungan puskesmas untuk memahami proses duka pada orang tua dengan kehilangan dan mengedukasikan berbagai strategi koping adaptif untuk meringankan duka pada orang tua dengan kehilangan perinatal.

\section{Ucapan Terima Kasih}

Peneliti mengucapkan terima kasih kepada Puskesmas Mantrijeron dan Puskesmas Pleret DIY dan seluruh ibu yang berpartisipasi dalam penelitian ini.

\section{Daftar Pustaka}

Arnold, J \& Gemma, P.B. 2008. Continuing Process of Parental Grief. Death Studies, 32(7): 658-673, doi: $10.1080 / 07481180802215718$

Badenhorst W, Hughes P. 2007. Psychological aspects of perinatal loss. Best Practice and Research. Clinical Obstetrics and Gynaecology, 21(2):249-59. 
Burden C, Bradley S, Storey C, Ellis A, Heazell AEP, Downe S, Cacciatore J, \& Siassakos D. 2016. From grief, guilt pain and stigma to hope and pride-a systematic review and meta-analysis of mixed-method research of the psychosocial impact of stillbirth. $B M C$ Pregnancy and Childbirth, 16:9.

Central of Disease Control and Prevention (CDC). 2018. Lack of Change in Perinatal Mortality in the United States, 2014-2016. Retrieved January 20, 2019 from https://www.cdc.gov/nchs/products/data briefs/db316.htm.

Frøen JF, Cacciatore J, McClure EM, Kuti O, Jokhio AH, Islam M, et al. 2011. Stillbirths: why they matter. Lancet 2011;377:1353-66.

Gould D. 2010. Transforming your life after the death of a child. Diakese dari https://www.fodsupport.org/documents/ TransformingyourlifeaftertheDeathofaC hild.pdf. Retrieved September 4, 2017.

Gupta P, Agasthiya AS, Nageshwer V. 2017. Grief, guilt and emptiness: emotional experiences of bereaved mothers after perinatal loss. Indian Journal of Obstetrics and Gynecology Research, 4(3):254-261. doi: 10.18231/23942754.2017.0057

Kavanaugh K, Trier D, \& Korzec. 2004. Social Support Following Perinatal Loss. Journal of Family Nursing, 10(1): 70-92.

Koopmans L, Wilson T, Cacciatore J, Flenady V. 2013. Support for mothers, fathers and families after perinatal death. Cochrane Database of Systematic Reviews, Issue 6. Art. $\quad$ No.: CD000452. DOI:10.1002/14651858.CD000452.pub 3.
Lindemann E. 1944. Symptomatology and Management of Acute Grief. American Journal of Psychiatry, 101: 141-148.

Maryam Allahdadian M, Irajpour A. 2015. The role of religious beliefs in pregnancy loss. J Educ Health Promot.; 4: 99.. doi: 10.4103/2277-9531.171813

Neff KD. 2009. The Role of Self-Compassion in Development: A Healthier Way to Relate to Oneself. Hum Dev. 52(4): 211214. doi: 10.1159/000215071.

O'Leary J. 2004. Grief and its impact on prenatal attachment in the subsequent pregnancy. Archives Women's Mental HealtH, 7:7-18.

Puia DM, Lewis L, \& Beck CT. 2013. Experiences of Obstetric Nurses Who Are Present for a Perinatal Loss. JOGNN, 42:321-331

SDKI. 2013. Survei Demografi dan Kesehatan Indonesia 2012. BKKBN, BPS, Kemenkes RI.

Ünstündag-Budak AM. 2015. The replacement child syndrome following stillbirth: a reconsideration. Dans Enfance 2015/3 ( N $\left.^{\circ} 3\right)$, pages 351 à 364

WHO. 2019. Maternal and perinatal health. Retrieved January 20, 2019 from https://www.who.int/maternal_child_ad olescent/topics/maternal/maternal_perin atal/en/

Zacharias, N. 2017. Perinatal Mortality. UpToDate. Retrieved July 29, 2017 from https://www.uptodate.com /contents/perinatal-mortality 